\title{
ANTSVORIO TURINČIŲ IR NUTUKIMU SERGANČIŲ VAIKŲ LAIKYSENA ANKSTYVOJOJE PAAUGLYSTĖJE
}

\author{
Vaiva Strukčinskaitė ${ }^{1}$, Skaistė Trijonyte் ${ }^{1}$, Birutė Strukčinskiene் $\dot{ }^{2}$, Neringa Strazdiené², \\ Aurelija Šidlauskienè ${ }^{1}$, Sigitas Griškonis ${ }^{2,3}$ \\ ${ }^{1}$ Vilniaus universitetas, ${ }^{2}$ Klaipédos universitetas, ${ }^{3}$ Klaipédos universitetiné ligoniné
}

Raktažodžiai: vaikai, paaugliai, antsvoris, nutukimas, laikysena.

\section{Santrauka}

Viena didžiausių pastarojo šimtmečio visuomenès sveikatos problemų - sparčiai didejjantis antsvorio turinčių ir nutukimu sergančių paauglių skaičius. Ankstyvosios paauglystès laikotarpiu (10-14 m.) paaugliu populiacijoje kyla vis daugiau sveikatos problemų, susijusių su svorio didejimu. Antsvoris ir nutukimas yra vieni iš pagrindinių rizikos veiksnių, kurie gali sukelti laikysenos, ortopedines, judamojo-atramos aparato problemas ateityje. Straipsnyje vertinama antsvorio turinčių ir nutukimu sergančių vaikų laikysena ankstyvojoje paauglysteje. Tyrimas atliktas 2018-2019 metais. Jame dalyvavo 20 antsvorio turinčių ar nutukimu sergančių 10-14 metų paauglių. Atlikti tiriamuju antropometriniai matavimai, remiantis DIERS 3D diagnostiniu tyrimo metodu, vertinti paauglių stuburo parametrai sagitalinejje, frontalineje ir horizontaliojoje plokštumose, taikytas W. W. K. Hoeger vizualinis laikysenos vertinimo testas, naudoti matematinès statistikos metodai.

Vertinant tiek mergaičiu , tiek berniukų grupes, buvo nustatytas labai aukštas procentinis kūno riebalų lygis, o skeletinių raumenų procentas paauglių organizme buvo mažas. Apskritai, kuo didesnis buvo tiriamųjų kūno masès indekso (KMI) rodiklis, tuo skeletinių raumenų procentas paauglių organizme buvo mažesnis. Be to, kuo buvo didesnis tiriamujų kūno riebalų kiekio procentas, tuo procentinis skeletinių raumenų kiekis paauglių organizme nustatytas statistiškai reikšmingai mažesnis.

Paauglių, turinčių antsvorio ir sergančių nutukimu, kifozinio ir lordozinio kampų, dubens pasisukimo rezultatai viršijo normas ir atitiko skoliozinès laikysenos rodiklius. Berniukų laikysena, nustatyta tai- kant W. W. Hoeger vizualini vertinimo metodą, kaklo ir viršutineje stuburo dalyje buvo statistiškai reikšmingai prastesnè nei mergaičių $(\mathrm{p}<0,05)$. Nustatyta statistiškai reikšminga neigiama koreliacija tarp tiriamujų dubens pasisukimo laipsnio ir laikysenos vertinimo: kuo mažesnis paauglių dubens pasisukimo laipsnis, tuo geresnis laikysenos vertinimas pagal W. W. Hoeger skalę $(\mathrm{p}<0,05)$.

\section{Ivadas}

Paauglystės amžiaus tarpsnis - svarbus vaiko augimo, vystymosi, brandos, asmenybès formavimosi, sveikatos stiprinimo ir sveikatai palankios elgsenos ugdymo(si) laikotarpis. Viena didžiausių XXI amžiaus visuomenès problemų - sparčiai didejjantis antsvorio turinčių ir nutukimu sergančių paauglių skaičius. Remiantis pasaulio sveikatos organizacijos (PSO) duomenimis, nustatyta, kad $2016 \mathrm{~m}$. visame pasaulyje 41 milijonas vaikų ir paauglių buvo nutukę ar turejjo antsvorio. Šią pasaulinio masto situaciją PSO ịvardijo kaip „epidemiją, globalų nutukimą“. Nustatyta, kad egzistuoja $60 \%$ tikimybè, jog vaikas ar paauglys, prieš brendimą turèjęs antsvorio, sirgs nutukimu ar turès per didelị svorị ir suaugęs [1].

Lietuvos Higienos instituto Sveikatos informacijos centro 2016 metų duomenimis, Lietuvos ugdymo ịstaigose mokèsi 286864 vaikai, kurių daugiau kaip pusè (62\%) buvo normalaus svorio. Likusią dali sudare vaikai, kurie buvo nutukę (5\%) arba turejjo antsvorio (14\%) [2].

Ankstyvosios paauglystes laikotarpiu (10-14 m.) paauglių populiacijoje kyla vis daugiau sveikatos problemų, susijusių su svorio didejimu: antrojo tipo cukrinis diabetas (CD), širdies ir kraujagysliu sistemos ligos, didelis cholesterolio kiekis kraujyje, ortopedinès ir judamojo-atramos aparato problemos [3,4]. Nors, anot A. Raza ir kt. (2017), vaikų bei paauglių antsvoris ir nutukimas nèra esminè netaisyklingos laikysenos priežastis, tačiau tai yra vienas pagrindinių rizikos faktorių, kuris gali sukelti ortopedines, judamojo-atramos 
aparato problemas ateityje [5]. Pastaraisiais metais prastejanti vaikų ir paauglių laikysena [6] skatina imtis laikysenos sutrikimų prevencijos ir korekcijos priemonių ankstyvojoje paauglysteje. Vaiko kūne prieš lytinę brandą ir jos metu vyksta ịvairūs morfologiniai ir funkciniai pokyčiai, organizmas turi sugebèti prie jų adaptuotis. M. Bélanger (2009) ir kt. mokslininkai teigia, kad svarbu nuo 7 iki 17 metų pastebeti ortopedines problemas, judamojo-atramos aparato sutrikimus ir imtis tikslingo, individualaus, diferencijuoto, laipsniško ir įvairiapusiško koregavimo [7].

Kadangi siekiama palaipsniui mažinti vaikų ir paauglių antsvorị bei nutukimą, K. Sahoo (2015) ir kt. tyrejai rekomenduoja sutelkti dėmesį jo prevenciją. Pirmasis žingsnis, kurị būtina atlikti - vaiko ir paauglio kasdienybès, mitybos, fizinio aktyvumo, miego režimo stebėsena. Šie rodikliai turi būti įvertinti specialistų, tuomet atliekama šių rodiklių korekcija, kuriamas individualus mitybos ir fizinio aktyvumo balansas [2].

Darbo tikslas - įvertinti antsvorio turinčių ir nutukimu sergančių vaikų laikyseną ankstyvojoje paauglystėje.

\section{Tyrimo medžiaga ir metodai}

Tyrimas buvo atliekamas $2018 \mathrm{~m}$. spalio-2019 m. balandžio mèn. Vaikų ligoninès, Všt Vilniaus Universiteto ligoninès Santaros klinikų filialo Fizinès medicinos ir reabilitacijos skyriuje. Pasirinktas kiekybinis momentinis tyrimo tipas. Tiriamoji imtis formuota, remiantis ittraukimo i tyrimą kriterijais (nustatytas antsvoris ar nutukimas, 10-14 m. vaikai, duotas tèvų leidimas dalyvauti tyrime). Tiriamieji ir jų tèvai buvo supažindinti su atliekamo tyrimo tikslu, uždaviniais, tyrimo eiga ir naudojamais metodais, gauti rašytiniai jų sutikimai dalyvauti tyrime. Atliekant tyrimą, buvo laikomasi Fizinès medicinos ir reabilitacijos skyriaus bei paciento (tiriamojo) konfidencialumą užtikrinančių reikalavimų.

Tyrime iš viso dalyvavo 20 antsvorio turinčių ar nutukimu sergančių 10-14 metų paauglių $(\mathrm{n}=20), 10$ mergaičių ir 10 berniukų. Tiriamujų amžiaus vidurkis buvo $11,90 \pm 1,51$ metai.

Antropometriniai matavimai. Tyrimo metu buvo vertinami vaikų antropometriniai duomenys, naudojant kūno analizatoriu (pavadinimas - BF511; modelis - HBF-511BE/HBF-511T-E) ir stadiometrą. Prieš kiekvieną matavimą buvo prašoma nusiauti batus, nusivilkti viršutinius rūbus bei kojines. Naudojant kūno kompozicijos analizatorių (tikslumas: kūno riebalai ir skeletiniai raumenys $+-3,5 \%$; svoris $+-0,4 \mathrm{~kg}$ ), buvo ịvertinami šie parametrai: svoris $(\mathrm{kg}), \mathrm{KMI}$ $\left(\mathrm{kg} / \mathrm{m}^{2}\right)$, kūno riebalai (\%), skeletiniai raumenys (\%). KMI reikšmè buvo nustatoma pagal Tarptautinès kovos su nutukimu darbo grupès (angl. IOTF - International Obesity Task Force) tarptautines ribines vertes. Šios KMI vertès buvo apibrèžiamos, atsižvelgiant ị paauglio lytị ir amžių. Paaugliai, kuriu KMI buvo $19,84-25 \mathrm{~kg} / \mathrm{m}^{2}$, priskirti antsvorio turinčiujų kategorijai, o paaugliai, kurių KMI buvo 24-30 kg/ $\mathrm{m}^{2}$ - nutukimu sergančiujų kategorijai.

Tiriamojo ūgis buvo matuojamas naudojant stadiometrą - standartinį vertikalų ūgio matuoklį (tikslumas $+-5 \mathrm{~mm}$ ). Atliekant matavimus, buvo laikomasi tam tikros kūno padèties reikalavimu.

DIERS 3D diagnostinis tyrimo metodas. DIERS Formetric 3D diagnostinè sistema buvo naudojama paaugliu judejimo-atramos aparato sutrikimams nustatyti. Tyrimo metu ši sistema ant tiesiai stovinčio, viršutinę kūno dalị apnuoginusio tiriamojo nugaros suprojektuoja baltai pilkos spalvos linijas. Tuomet fiksuojamas paviršiaus vaizdas, kad būtų užfiksuota tiksli kūno taškų asimetrija ir nustatytos tam tikros kaulinès struktūros (pvz.: apatiniai menčių kampai, kryžkaulio duobutès, stuburas). Pèdos nerotuotos, jų plotis atitinka pečių plotį. Rankos nuleistos prie šlaunų, žvilgsnis nukreiptas tiesiai ị sieną. Kūno padètis testavimo metu turejjo būti natūrali, atpalaiduota. Buvo atliekamas stuburo parametrų vertinimas sagitalineje, frontalineje ir horizontaliojoje plokštumose [8]. Naudojantis kompiuterine programa, parametrai buvo apskaičiuojami ir palyginami, atkuriamas trimatis tiriamojo nugaros vaizdas. Tyrimo metu vaiko organizmo žalinga radiacija neveikè. Sagitalinėje plokštumoje, naudojantis DIERS 3D diagnostine sistema, îvertinti ir analizuoti šie stuburo parametrai:

- Liemens disbalansas (mm) - šoninis atstumas tarp C7 slankstelio ir dubens vidurio. Liemens disbalansas neturètu viršyti $7,5^{\circ} \mathrm{mm}$. Norma: $>5^{\circ} \mathrm{mm}$ - skoliozinè laikysena; $>>5^{\circ} \mathrm{mm}$ - skoliozè.

- Kifozinis kampas $\left(^{\circ}\right)$ nurodo krūtininio linkio gylị. Norma $45^{\circ}-50^{\circ}$.

- Lordozinis kampas $\left(^{\circ}\right)$ nurodo juosmens linkio gyli. Norma $38^{\circ}-42^{\circ}[9]$.

Frontalinejje plokštumoje DIERS 3D diagnostine sistema ivertintas ir analizuotas stuburo parametras - dubens pakrypimas $(\mathrm{mm})$. Šis parametras išreiškia aukščio tarp kryžkaulio duobučių skirtumą. Norma: $>4^{\circ} \mathrm{mm}$ - skoliozinè laikysena; skoliozè [9].

Horizontaliojoje plokštumoje DIERS 3D diagnostine sistema iqvertintas ir analizuotas stuburo parametras - dubens pasisukimas $\left({ }^{\circ}\right)$. Parametras nurodo dubens sukimąsi apie vertikaliają ašį. Dubens pasisukimas yra matuojamas pagal dešinijj šlaunikaulị, kuris gali būti pasisukęs arba ị prieki $(+)$, arba atgal (-). Norma: $<2^{\circ}-$ skoliozinè laikysena, skoliozè [9].

W. W. K. Hoeger vizualinis tyrimo metodas. Paaugliu laikysenai įvertinti taikytas W. W. K. Hoeger 1987 metu vizualinis laikysenos vertinimo testas [10]. Naudojant ši 
testą, buvo ịvertinta 10 atskirų kūno segmentų (galva, pečiai, stuburas, dubuo, keliai ir čiurnos, kaklas ir viršutinè stuburo dalis, liemuo, pilvas, apatinè stuburo dalis, kojos). Apžiūrint laikyseną iš nugaros, buvo įvertinta galvos padètis, pečių lanko simetrija, menčių ir dubens simetrija, stuburo, kelių ir čiurnų padètis. Apžiūrint laikyseną iš šono, buvo ịvertinta galvos padètis, atkreipiamas dèmesys į fiziologinius stuburo linkius, pilvo, apatinès stuburo dalies ir kojų padètį. Laikysenos vertinimas atliekamas dviejose plokštumose: frontalinėje ir sagitalinèje. Pagal W. W. Hoeger metodą, kiekvienas atskiras kūno segmentas įvertinamas balais- nuo 1 iki 5 balų ( 1 - blogai, 3 - patenkinamai, 5 - gerai), po to atliktas laikysenos ivvertinimas, suskaičiavus visų gautų balų sumą (1 lentelè).

Vizualinis laikysenos vertinimo testas atliekamas nusirengus viršutinius rūbus ir nusiavus batus. Tyrimo metu tiriamasis turi būti atsipalaidavęs, natūralioje padètyje, rankos nuleistos prie šlaunų.

Statistinei duomenu analizei atlikti buvo naudojamas statistikos programų paketas IBM SPSS 25.0 ir Excel 2016 programa. Apskaičiuoti kiekybinių duomenų aritmetiniai vidurkiai, standartiniai nuokrypiai (SD), duomenų aibès plotis (min-max reikšmè), duomenų dažnių pasiskirstymas. Tyrimo imties dydis buvo mažesnis nei 50 asmenų, todèl, tikrinant, ar duomenys buvo pasiskirstę pagal normalujį skirstini, buvo naudojamas Šapiro-Vilko testas. Analizuojant duomenis, kurie pasiskirstę pagal normalujį skirstinį, rodikliams palyginti buvo taikyta parametrinè duomenų analizè, o duomenims, kurie nebuvo pasiskirstę pagal normalujji skirstini - neparametriné duomenų analizè. Koreliaciniams ryšiams tarp gautų rodiklių apskaičiuoti buvo naudojamas Spearmano koreliacijos koeficientas (r) (kintamiesiems, kurie nebuvo pasiskirstę pagal normalujį skirstinị) ir Pearsono koreliacijos koeficientas (r) (kintamiesiems, kurie buvo pasiskirstę pagal normalujji skirstini). Koreliacijos stiprumas vertintas intervalais: labai stiprus statistinis ryšys $-r> \pm 0,90$, stiprus $-r> \pm 0,70-0,89$, vidutinio stiprumo $-r> \pm 040-0,69$, silpnas $-r> \pm 0,20-0,39$, labai silpnas $-r<0,20$. Duomenų skirtumai buvo laikomi statistiškai reikšmingi, kai $\mathrm{p}<0,05$.

\section{Tyrimo rezultatai ir jų aptarimas}

Paauglių antropometrinių duomenų analizè. Nustatyta, kad tiriamujų ūgis svyravo nuo 140 iki $180 \mathrm{~cm}$, o ūgio vidurkis buvo

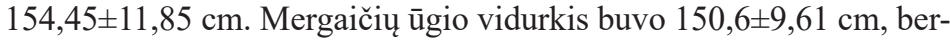

1 lentelè. Laikysenos ịvertinimas pagal W. W. Hoeger metodą.

\begin{tabular}{|l|c|}
\hline Balai & $\begin{array}{c}\text { Laikysenos iverti- } \\
\text { nimas }\end{array}$ \\
\hline $50-45$ & Puiki \\
\hline $44-40$ & Gera \\
\hline $39-30$ & Patenkinama \\
\hline $29-20$ & Bloga \\
\hline$<19$ & Labai bloga \\
\hline
\end{tabular}
balų lygio rezultatai. niukų - 164,6 $\pm 9,98 \mathrm{~cm}$.

Antsvorio turinčių ar nutukimu sergančių paauglių svoris svyravo nuo 49,50 kg iki $117 \mathrm{~kg}$, o svorio vidurkis buvo $74,45 \pm 18,56 \mathrm{~kg}$. Nustatytas mergaičių svorio vidurkis $-69,8 \pm 13,86 \mathrm{~kg}$, berniukų $-79,3 \pm 22,09 \mathrm{~kg}$.

Ivertinus antsvorio turinčių ir nutukimu sergančių paauglių ūgio ir svorio rodiklius, naudojantis kūno sudèties analizatoriumi, buvo nustatytas KMI rodiklis, kurio reikšmé svyravo nuo 22,60 iki $36,10 \mathrm{~kg} / \mathrm{m}^{2}$. Tiriamųjų KMI vidurkis buvo $29,60 \pm 3,87 \mathrm{~kg} / \mathrm{m}^{2}$. Pagal KMI tarptautines ribines vertes, KMI rodiklis atitinka nutukimo reikšmę, atsižvelgiant tiek ị vyriškają, tiek ị moteriškają lytị ir amžių. Mergaičių KMI vidurkis buvo $30,43 \mathrm{~kg} /$ $\mathrm{m}^{2}$ (KMI rodiklis atitinka nutukimą), o berniukų $28,77 \mathrm{~kg} / \mathrm{m}^{2}$ (KMI rodiklis atitinka nutukimą). Nustatyta, kad $30 \%$ paauglių turèjo antsvorio, o $70 \%$ sirgo nutukimu. Mergaičių grupejje antsvorio turèjo $10 \%$ moteriškos lyties atstovių, $90 \%$ jų buvo nustatytas nutukimas. Apžvelgiant berniukų KMI rodiklio rezultatus, nustatyta, kad $30 \%$ berniukų turejjo antsvorio, o likusieji $70 \%$ sirgo nutukimu.

Kitas su padidejjusiu kūno svoriu susijęs paauglių organizmo rodiklis - procentinis kūno riebalų kiekis - svyravo nuo 30,10 \% iki 43,20 \%, o šio rodiklio vidurkis $-34,72 \pm 3,58 \%$. Mergaičių

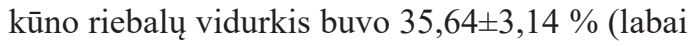
aukštas procentinis kūno riebalų lygis), mažiausia nustatyta rodiklio reikšmé $-31,70 \%$, didžiausia - 41,50 \%. Berniukų kūno riebalų rodiklis buvo

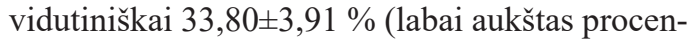
tinis kūno riebalų lygis) ir svyravo nuo 30,10 iki 43,20\%. Bendroje grupejje labai aukštą kūno riebalų lygị turèjo $55 \%$ tiriamujų, aukštą - $45 \%$. Daugiau kaip pusei (60\%) mergaičių nustatytas aukštas kūno riebalų kiekis organizme, 40 \% - labai aukštas lygis. Didžiajai daliai (70 \%) berniukų nustatytas labai aukštas kūno riebalų kiekio lygis, o aukštas - $30 \%$ (2 lentelè).

İvertinus paauglių procentinị skeletinių rau2 lentelè. Paauglių procentinio kūno rie-

\begin{tabular}{|l|c|c|}
\hline Grupé (lytis) & $\begin{array}{c}\text { Aukštas } \\
\text { lygis }\end{array}$ & $\begin{array}{c}\text { Labai aukš- } \\
\text { tas lygis }\end{array}$ \\
\hline Bendra grupe & $45 \%$ & $55 \%$ \\
\hline Mergaitè & $60 \%$ & $40 \%$ \\
\hline Berniukai & $30 \%$ & $70 \%$ \\
\hline
\end{tabular}
menų kiekị organizme, buvo nustatyta, kad šio rodiklio vidurkis yra $30,06 \pm 3,18 \%$, mažiausia nustatyta reikšmè - $22,40 \%$, o didžiausia $-35,10 \%$. Mergaičių organizmo skeletinių raumenų rodiklis vidutiniškai buvo $29,12 \pm 2,63 \%$. Rezultatai svyravo nuo 23,40 iki 33,20 \%. Berniukų organizmo skeletinių raumenų kiekio vidurkis buvo $31,00 \pm 3,52 \%$ ir rezultatai svyravo nuo $22,40 \mathrm{iki}$ $35,10 \%$. 
Antsvorio turinčių ir nutukimu sergančių tiriamųjų KMI rodiklis turejjo stiprų, statistiškai reikšmingą teigiamą ryši su procentiniu kūno riebalų kiekiu paauglių organizme $\left(r=0,828^{*} ; p=0,000\right)$. Šis koreliacinis ryšys rodo, kad paaugliai, kurie turèjo didesnị kūno riebalų procentą, pasižymèjo didesniu KMI. Taip pat nustatyta, kad KMI rodiklis turejo vidutinio stiprumo statistiškai reikšmingą neigiamą ryši su procentiniu skeletinių raumenų kiekiu organizme $\left(\mathrm{r}=-, 698^{* *} ; \mathrm{p}=0,001\right)$. Šis ryšys parodo, kad kuo didesnis buvo tiriamuju KMI rodiklis, tuo paauglių organizmo skeletinių raumenų procentas buvo mažesnis. Apskaičiavus koreliacini ryši tarp tiriamųjų procentinio kūno riebalų kiekio ir procentinio skeletinių raumenų kiekio, nustatytas labai stiprus, statistiškai reikšmingas, neigiamas ryšys $(r=-, 879 * *, p=0,000)$. Ši koreliacija rodo, kad kuo kūno riebalų kiekio procentas buvo didesnis - tuo procentinis skeletinių raumenų kiekis paauglių organizme buvo mažesnis (3 lentelè).

Paauglių laikysenos rezultatų analizė naudojant W. W. Hoeger vizualinị vertinimo metodą. Vidutinis antsvorio turinčiu ir nutukimu sergančių paauglių laikysenos ịvertinimas pagal W. W. Hoeger (1987) vizualini vertinimo metodą buvo $40,10 \pm 2,93$ balo, tai interpretuojama kaip gera laikysena (40-44 balai). Paauglių laikysenos vertinimo balai svyravo nuo 34 iki 48 balų, o tai galima interpretuoti nuo patenkinamos iki puikios laikysenos siekiančiu vertinimu. Nustatytas mergaičiu laikysenos vertinimo vidurkis buvo 40,00 $\pm 3,29$ balo (gera laikysena), mažiausias įvertinimas siekè 35 balus, o didžiausias -47 balus. Ivertinus berniukų laikyseną, nustatytas vidurkis buvo $39,20 \pm 2,42$ balo (patenkinama laikysena). Vyriškosios lyties populiacijos laikysenos vertinimas svyravo nuo 34 iki 42 balų, o tai interpretuojama kaip ịvertinimas, siekiantis nuo patenkinamos iki geros laikysenos.

Frontalinèje plokštumoje ịvertintų paauglių kūno segmentų rezultatų vidurkiai pateikti 1 paveiksle. Atskiri kūno segmentai vertinti pagal W. W. Hoeger metodą: 1 balas - „blogai“, 3 balai - ,patenkinamai“ ir 5 balai atitinka vertinimą ,puikiai““.

Atskirų tiriamųjų kūno dalių padečių vertinimo vidurkiai sagitalinèje plokštumoje pateikti 2 paveiksle. Atlikus skaičiavimus, nustatyta, kad kaklo ir viršutinès stuburo dalies vidurkis buvo $3,20 \pm 0,82$ balo, liemens padèties vidurkis $-4,00 \pm 1,02$ balo, pilvo padèties $-2,60 \pm 0,82$ balo, apatinès stuburo dalies $-3,50 \pm 1,00$ balo, o kojų padèties vidurkis $-4,50 \pm 0,88$ balo.

Atsižvelgiant i 1 ir 2 paveiksle pavaizduotus rezultatus, 3 paveiksle pateiktas

3 lentelè. Paauglių antropometrinių duomenų tarpusavio sąsajos

$r-$ koreliacijos koeficientas, ${ }^{* *} p<0,001$

\begin{tabular}{|c|c|c|c|}
\hline Antropometriniai duomenys & KMI & Kūno riebalai & Skeletiniai raumenys \\
\hline KMI & & $\begin{array}{c}\mathrm{r}=, 828 * * \\
\mathrm{p}=0,000\end{array}$ & $\begin{array}{c}\mathrm{r}=-, 698 * * \\
\mathrm{p}=0,001\end{array}$ \\
\hline Kūno riebalai & $\begin{array}{c}\mathrm{r}=, 828^{* *} \\
\mathrm{p}=0,000\end{array}$ & & $\begin{array}{c}\mathrm{r}=-, 879 * * \\
\mathrm{p}=0,000\end{array}$ \\
\hline Skeletiniai raumenys & $\begin{array}{c}\mathrm{r}=-, 698 * * \\
\mathrm{p}=0,001\end{array}$ & $\begin{array}{c}\mathrm{r}=-, 879 * * \\
\mathrm{p}=0,000\end{array}$ & \\
\hline
\end{tabular}

4 lentelè. Tiriamujų DIERS 3D parametrų rezultatai.

\begin{tabular}{|l|c|c|c|}
\hline DIERS 3D parametrai & $\begin{array}{c}\text { Mažiausias } \\
\text { ivertinimas }\end{array}$ & $\begin{array}{c}\text { Didžiausias } \\
\text { ivertinimas }\end{array}$ & Vidurkis \pm SD \\
\hline Liemens disbalansas $(\mathrm{mm})$ & 1 & 9 & $4,40 \pm 2,64$ \\
\hline Dubens pakrypimas $(\mathrm{mm})$ & 0 & 9 & $3,20 \pm 2,60$ \\
\hline Dubens pasisukimas $\left(^{\circ}\right)$ & 0 & 6 & $3,10 \pm 1,80$ \\
\hline Kifozinis kampas $\left(^{\circ}\right)$ & 39 & 71 & $54,75 \pm 11,36$ \\
\hline Lordozinis kampas $\left(^{\circ}\right)$ & 32 & 64 & $49,60 \pm 9,32$ \\
\hline
\end{tabular}

5 lentelè. DIERS 3D parametrų sąsajos su W. W. Hoeger vizualinio laikysenos vertinimo metodo balu suma.

$r$-koreliacijos koeficientas, ${ }^{*} p<0,05$

\begin{tabular}{|c|c|c|c|c|c|c|}
\hline $\begin{array}{l}\text { DIERS 3D / } \\
\text { W. W. Hoe- } \\
\text { ger metodas }\end{array}$ & $\begin{array}{c}\text { Liemens } \\
\text { disbalansas } \\
(\mathrm{mm})\end{array}$ & $\begin{array}{c}\text { Dubens pa- } \\
\text { krypimas } \\
(\mathrm{mm})\end{array}$ & $\begin{array}{c}\text { Dubens } \\
\text { pasisuki- } \\
\text { mas }\left(^{\circ}\right)\end{array}$ & $\begin{array}{c}\text { Kifozinis } \\
\text { kampas } \\
\left(^{\circ}\right)\end{array}$ & $\begin{array}{l}\text { Lordozinis } \\
\operatorname{kampas}\left(^{\circ}\right)\end{array}$ & $\begin{array}{c}\text { W. W. } \\
\text { Hoeger } \\
\text { metodas } \\
\text { (balai) }\end{array}$ \\
\hline $\begin{array}{l}\text { Liemens } \\
\text { disbalansas } \\
(\mathrm{mm})\end{array}$ & & $\begin{array}{l}r=-0,005 \\
p=0,0985\end{array}$ & $\begin{array}{l}r=0,165 \\
p=0,487\end{array}$ & $\begin{array}{l}r=-0,265 \\
p=0,260\end{array}$ & $\begin{array}{l}r=-0,209 \\
p=0,377\end{array}$ & $\begin{array}{l}\mathrm{r}=0,022 \\
\mathrm{p}=0,928\end{array}$ \\
\hline $\begin{array}{l}\text { Dubens } \\
\text { pakrypimas } \\
(\mathrm{mm})\end{array}$ & $\begin{array}{l}r=-0,005 \\
p=0,985\end{array}$ & & $\begin{array}{l}r=-0,035 \\
p=0,883\end{array}$ & $\begin{array}{l}r=0,025 \\
p=0,917\end{array}$ & $\begin{array}{l}r=-0,133 \\
p=0,576\end{array}$ & $\begin{array}{l}\mathrm{r}=-0,333 \\
\mathrm{p}=0,152\end{array}$ \\
\hline $\begin{array}{l}\text { Dubens } \\
\text { pasisukimas } \\
\left({ }^{\circ}\right)\end{array}$ & $\begin{array}{l}r=0,165 \\
p=0,487\end{array}$ & $\begin{array}{l}\mathrm{r}=0,035 \\
\mathrm{p}=0,883\end{array}$ & & $\begin{array}{l}\mathrm{r}=0,366 \\
\mathrm{p}=0,112\end{array}$ & $\begin{array}{l}r=-0,402 \\
p=0,079\end{array}$ & $\begin{array}{l}r=-, 494^{*} \\
p=0,027\end{array}$ \\
\hline $\begin{array}{l}\text { Kifozinis } \\
\text { kampas }\left({ }^{\circ}\right)\end{array}$ & $\begin{array}{l}\mathrm{r}=-0,265 \\
\mathrm{p}=0,260\end{array}$ & $\begin{array}{l}\mathrm{r}=0,025 \\
\mathrm{p}=0,917\end{array}$ & $\begin{array}{l}\mathrm{r}=0,366 \\
\mathrm{p}=0,112\end{array}$ & & $\begin{array}{l}\mathrm{r}=0,130 \\
\mathrm{p}=0,584\end{array}$ & $\begin{array}{l}\mathrm{r}=0,317 \\
\mathrm{p}=0,174\end{array}$ \\
\hline $\begin{array}{l}\text { Lordozinis } \\
\text { kampas }\left({ }^{\circ}\right)\end{array}$ & $\begin{array}{l}r=-0,209 \\
p=0,377\end{array}$ & $\begin{array}{l}\mathrm{r}=-0,133 \\
\mathrm{p}=0,576\end{array}$ & $\begin{array}{l}\mathrm{r}=-0,402 \\
\mathrm{p}=0,079\end{array}$ & $\begin{array}{l}\mathrm{r}=0,130 \\
\mathrm{p}=0,584\end{array}$ & & $\begin{array}{l}r=-0,171 \\
p=0,472\end{array}$ \\
\hline $\begin{array}{l}\text { W. W. Hoe- } \\
\text { ger (balai) }\end{array}$ & $\begin{array}{l}\mathrm{r}=0,022 \\
\mathrm{p}=0,928\end{array}$ & $\begin{array}{l}r=-0,333 \\
p=0,152\end{array}$ & $\begin{array}{l}r=-, 494^{*} \\
p=0,027\end{array}$ & $\begin{array}{c}\mathrm{r}=-0,293 \\
\mathrm{p}=0,211\end{array}$ & $\begin{array}{l}\mathrm{r}=0,317 \\
\mathrm{p}=0,173\end{array}$ & \\
\hline
\end{tabular}


pagal W. W. Hoeger vizualini laikysenos vertinimo testą ịvertintų tiriamųjų trijų kūno segmentų - kaklo ir viršutinès stuburo dalies, pilvo, apatinès stuburo dalies -pasiskirstymas pagal balus. Vertinant šiuos kūno segmentus išryškejjo mažiausi vertinimo balai. Svarbu pažymèti, kad nẻ vieno iš tiriamujų nè vienas kūno segmentas nebuvo įvertintas žemiausiu balu (1). Nustatyta, kad berniukai turèjo statistiškai reikšmingai prastesni kaklo ir viršutinès stuburo dalies rodiklio ìvertinimą, lyginant su mergaitemis $(p=0,029)$.

Paauglių laikysenos ir stuburo parametrų rezultatai naudojant DIERS 3D diagnostinị tyrimo metodą. Remiantis DIERS 3D diagnostine sistema, paauglių laikysena buvo vertinama trijose plokštumose: sagitalineje, frontalineje ir horizontaliojoje. Ivertinus antsvorio turinčių ir nutukimu sergančių paauglių laikyseną DIERS 3D diagnostine sistema, buvo nustatyti šie parametrai: liemens disbalansas ( $\mathrm{mm})$, dubens pakrypimas $(\mathrm{mm})$, dubens pasisukimas $\left(^{\circ}\right)$, kifozinis kampas $\left({ }^{\circ}\right)$, lordozinis kampas $\left({ }^{\circ}\right)$. Gauti duomenys pateikti 4 lentelèje.

Sagitalinèje plokštumoje buvo ịvertinti ir išanalizuoti liemens disbalanso $(\mathrm{mm})$, kifozinio $\left(^{\circ}\right)$ ir lordozinio $\left(^{\circ}\right)$ kampų parametrai. Atlikto tyrimo metu buvo nustatyta, kad bendroje tiriamųu grupejje liemens disbalanso rezultatų vidurkis buvo $4,40 \pm 2,64 \mathrm{~mm}$, kifozinio kampo rezultatų vidurkis $-54,75 \pm 11,36^{\circ}$, lordozinio kampo rezultatų vidurkis $-49,60 \pm 9,32^{\circ}$.

Frontalinejje plokštumoje buvo įvertintas ir išana-

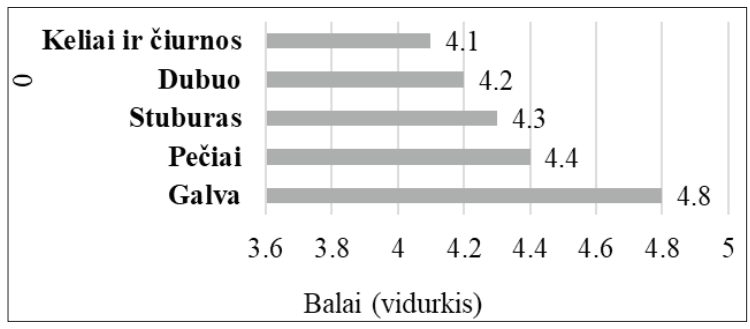

1 pav. Frontalinèje plokštumoje ịvertintų tiriamųjų kūno dalių paděčių rezultatų vidurkiai.

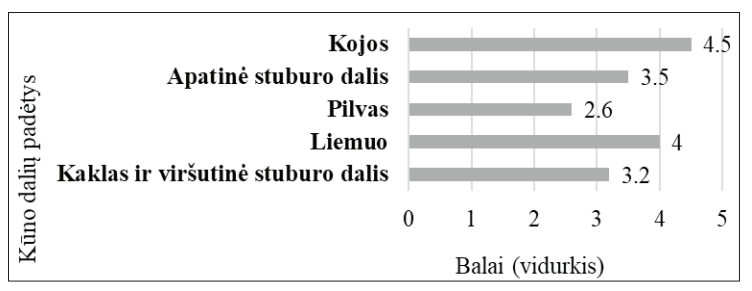

2 pav. Sagitalinėje plokštumoje įvertintų tiriamųjų kūno segmentų rezultatų vidurkiai.

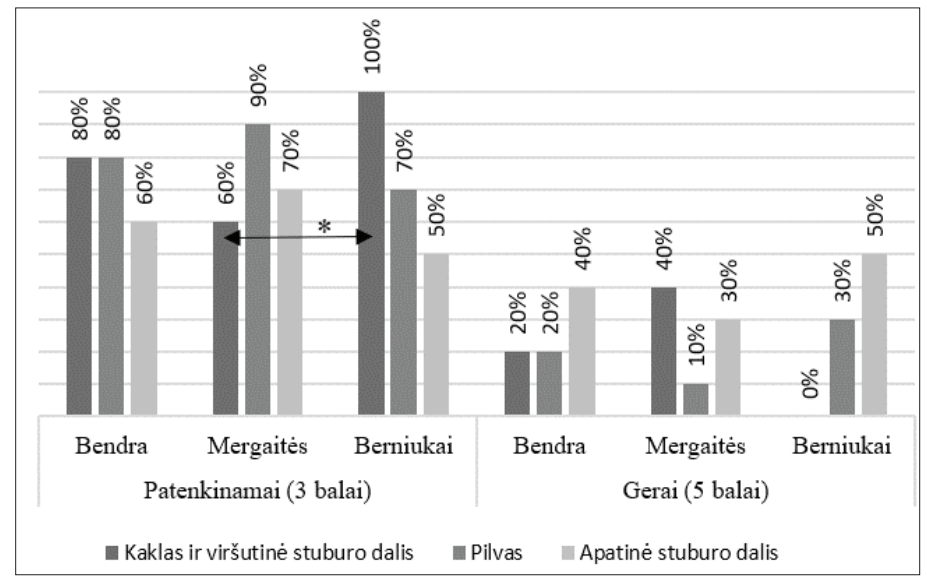

3 pav. Tiriamųjų pasiskirstymas pagal prasčiausiai ịvertintus kūno segmentus. ${ }^{*} p<0,05$

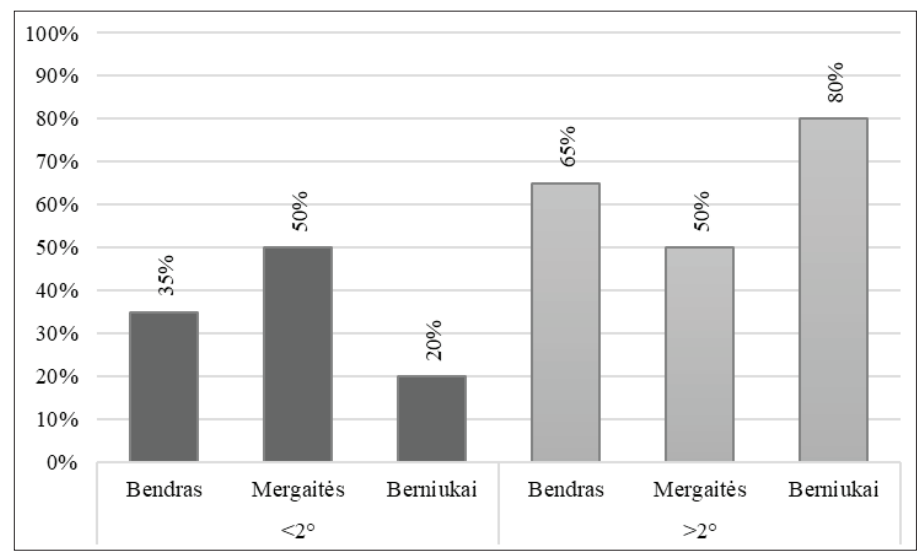

4 pav. Tiriamųų dubens pasisukimo pasiskirstymas pagal DIERS 3D normas.

lizuotas dubens pakrypimo $(\mathrm{mm})$ parametras. Bendroje tiriamujų grupeje buvo nustatytas $3,20 \pm 2,60 \mathrm{~mm}$ dubens pakrypimo vidurkis.

Horizontaliojoje plokštumoje buvo ịvertintas dubens pasisukimo $\left(^{\circ}\right)$ parametras. Bendroje tiriamujų grupeje nustatytas $2,10 \pm 1,80^{\circ}$ dubens pasisukimo vidurkis.

Atsižvelgus ị DIERS 3D diagnostinès sistemos instrukcijoje pateiktas rezultatu interpretacijas bei remiantis gautais kifozinio, lordozinio kampų ir dubens pasisukimo parametro rezultatų vidurkiais, galima teigti, kad antsvorio turintys ir nutukimu sergantys paaugliai turejo polinkị ị skoliozinę laikyseną (4-6 pav.).

Tiriamujų dubens pasisukimo pasiskirstymas pagal DIERS 3D nustatytas rezultatų interpretacijas pateiktas 4 paveiksle. Atsižvelgiant ị DIERS 3D instrukcijose pateiktą šio parametro normą $\left(<2^{\circ}\right)$, nustatyta, kad daugiau kaip pusė $(65 \%)$ visų tiriamujų $(50 \%$ mergaičių ir 80 \% berniukų) turejjo polinkị ị skoliozinę laikyseną ir viršijo nustatytą normą. 
Fiziologinių stuburo linkių rezultatų pasiskirstymas pateiktas 5 ir 6 pav. Nustatyta, kad tiriamujų kifozinio kampo rezultatai viršijo DIERS 3D instrukcijose interpretuojamą normą $\left(47^{\circ}-50^{\circ}\right)$ ir polinki i i skoliozinę laikyseną turèjo $25 \%$ visų tiriamujų (70\% mergaičių ir $80 \%$ berniukų) (5 pav.).

Lordozinio linkio normą $\left(38^{\circ}-42^{\circ}\right)$ viršijo ir polinkị ị skoliozinę laikyseną turèjo didžioji dauguma ( $80 \%)$ tiriamujų bendroje grupeje ( $70 \%$ mergaičiu ir $80 \%$ berniukų) (6 pav.). Dauguma tiriamųjų turèjo padidejjusị lordozinị ir kifozinį linkius.

Analizuojant pagal W. W. Hoeger ir DIERS 3D laikysenos vertinimo metodikas gautų rezultatų koreliacinius ryšius, nustatyta, kad vizualinio W. W. Hoeger laikysenos vertinimo metodo rezultatai statistiškai reikšmingai neigiamai koreliavo su DIERS 3D diagnostinès sistemos parametru - dubens pasisukimu $(\mathrm{r}=-, 494 *$; $\mathrm{p}=0,027)$. Tai rodo, kad kuo didesnis dubens pasisukimo kampas, tuo prastesni laikysenos vertinimo rezultatai. Tačiau apskaičiavus kitus koreliacinius ryšius tarp DIERS 3D diagnostinès sistemos parametrų rezultatų ir W. W. Hoeger vizualinio laikysenos vertinimo metodo balu sumos, nustatyti statistiškai nereikšmingi teigiami ir neigiami koreliaciniai ryšiai (5 lentelè).

Remiantis mūsų atlikto tyrimo duomenimis, vertinant antsvorio turinčių ir nutukimu sergančių paauglių laikyseną pagal W. W. Hoeger vizualinị laikysenos vertinimo metodą, bendroje grupeje tiriamujų laikysenos rezultatų vidurkis buvo $40,10 \pm 2,93$ balo, o tai atitinka geros laikysenos įvertinimą. O taikant W. W. Hoeger metodą per $2016 \mathrm{~m}$. atliktą tyrimą, paauglių kūno

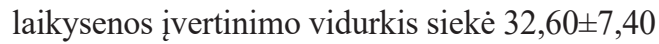
balo, kas atitinka patenkinamos laikysenos kategoriją [11].

Atlikus mergaičių laikysenos įvertinimą, nustatytas vidurkis buvo $40,00 \pm 3,29$ balo (gera laikysena), o berniukų laikysena ịvertinta 39,20 $\pm 2,42$ balo (patenkinama laikysena). Vertinant laikyseną, nustatytas statistiškai reikšmingas skirtumas tarp berniukų ir mergaičių. Berniukų laikysena buvo prastesnè, lyginant su mergaičių laikysena $(p=0,029)$. Pagal $2017 \mathrm{~m}$. atlikto tyrimo duomenis, antsvorio turinčių / nutukimu sergančių berniukų laikysena taip pat buvo statistiškai reikšmingai prastesnè, lyginant su mergaičių laikysena $(\mathrm{p}<0,001)[12]$.

Per ši tyrimą vertinant antsvorio turinčiu ir nutukimu sergančių paauglių laikyseną DIERS 3D paviršinès topografijos principu veikiančia diagnostine sistema, nustatyta, jog bendroje grupeje tiriamujų liemens disbalanso rezultatų vidurkis buvo $4,40 \pm 2,64 \mathrm{~mm}$, kifozinio kampo rezultatu vidurkis $-54,75 \pm 11,36^{\circ}$, dubens pakrypimo vidurkis $-3,20 \pm 2,60$ $\mathrm{mm}$, dubens pasisukimo parametro rezultatu vidurkis $-2,10 \pm 1,80^{\circ}$. Remiantis DIERS 3D diagnostinès sistemos instrukcijose nurodytomis rezultatų interpretacijomis, galima teigti, kad dubens pasisukimo, kifozinio ir lordozinio kampo parametrų rezultatų vidurkiai viršijo nustatytą normą. Per kitų tyrèjų atliktą tyrimą nustatyta, kad 46,8 \% nutukimu sergančių tiriamujų turèjo laikysenos sutrikimų (vertinamų sagitalinėje plokštumoje), t. y. nustatyti padidèję fiziologinių stuburo linkių kampų rodikliai $(\mathrm{p}<0,05)$ [13]. Koreliacinès analizès metu, lyginant DIERS $3 \mathrm{D}$ metodu gautus duomenis ir W. W. Hoeger vizualinio vertinimo testo rezultatus, nustatyta, kad kuo didesnis dubens pasisukimo kampas, tuo prastesni laikysenos vertinimo rezultatai.

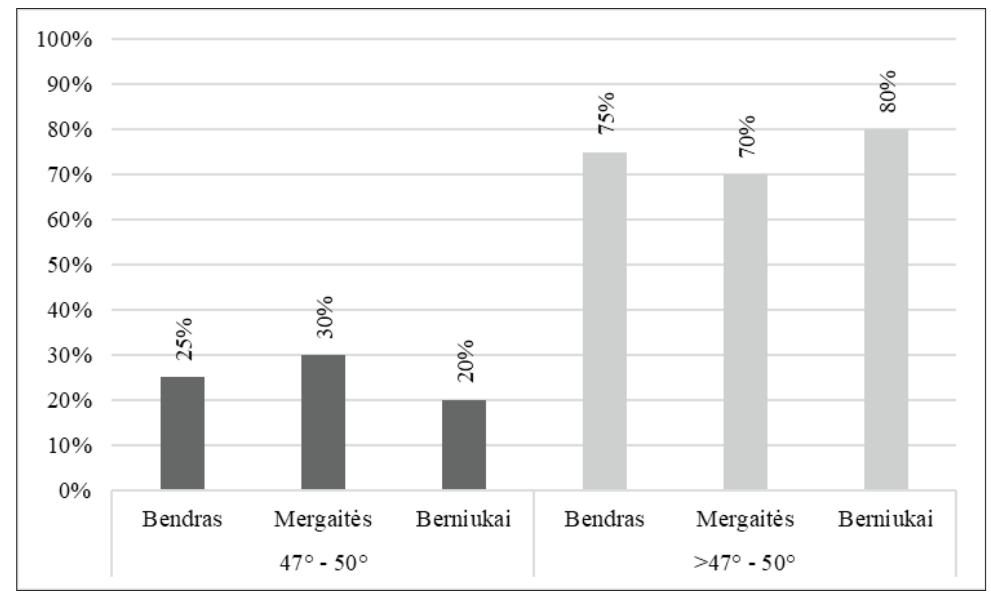

5 pav. Tiriamųjų kifozinio kampo pasiskirstymas pagal DIERS 3D normas.

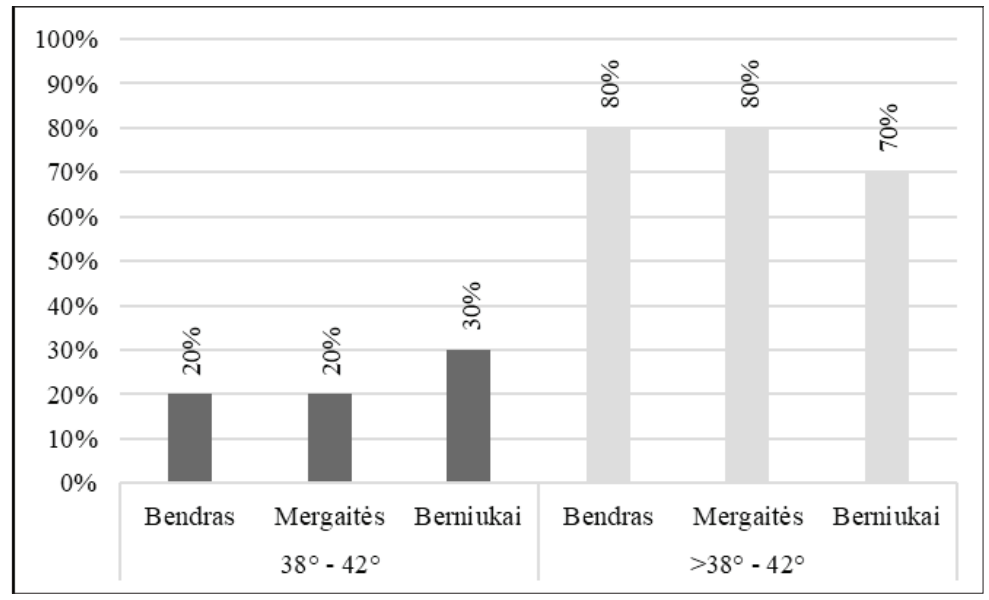

6 pav. Tiriamujų lordozinio kampo pasiskirstymas pagal DIERS 3D normas. 
Tyrimo metu atlikta koreliacinè analizè, lyginant tiriamųju procentinį kūno riebalų ir skeletinių raumenų kiekį bei KMI rodikli. Nustatyta, kad antsvorio turinčių ir nutukimu sergančių tiriamujų KMI rodiklis turejjo stiprų, statistiškai reikšmingą, teigiamą ryšį su procentiniu kūno riebalų kiekiu paauglių organizme $(\mathrm{r}=0,828 * *)$. Po mokslininkų $2016 \mathrm{~m}$. atlikto tyrimo gauta išvada, jog antsvorio turinčių ar nutukimu sergančių paauglių procentinis kūno riebalų, procentinis skeletinių raumenų kiekis organizme ir fizinio aktyvumo lygis statistiškai reikšmingai siejasi su vaikų ir paauglių kūno laikysena $(\mathrm{p}<0,001)[14]$.

Šiame straipsnyje aprašyto tyrimo trūkumas buvo tas, kad tiriamujų imtis - nereprezentatyvi. Kadangi tyrime dalyvavo dvidešimt Vilniaus miesto 10-14 metų amžiaus paauglių, atlikto tyrimo rezultatai neatspindi visos ankstyvosios paauglystès laikotarpio paauglių populiacijos. Būtų naudinga atlikti išsamesnius ankstyvają paauglystę patiriančių vaikų, kurie turi antsvorio ar serga nutukimu, laikysenos tyrimus, išplečiant tiriamujų imți, vertinant šio amžiaus paauglių laikyseną bei lyginant tiriamujų antropometrinius duomenis ir laikysenos rezultatus su normalų kūno svorị turinčių paauglių rezultatais.

\section{Išvados}

1. Trečdalis tyrime dalyvavusių 10-14 metų amžiaus paauglių turéjo antsvorio, o didesnè tiriamụjų dalis buvo nutukę. Tiek mergaičiu, tiek berniukų grupèse buvo nustatytas labai aukštas procentinis kūno riebalų lygis. Paaugliai, kurie turèjo didesnị kūno riebalų procentą, turejo ir didesnị KMI. Kuo didesnis buvo tiriamujų KMI rodiklis, tuo skeletinių raumenų procentas paauglio organizme buvo mažesnis. Kuo didesnis buvo tiriamujų kūno riebalų kiekis procentais, tuo procentinis skeletinių raumenų kiekis paauglių organizme buvo mažesnis.

2. Turinčių antsvorio ir sergančių nutukimu 10-14 m. amžiaus paauglių kifozinio ir lordozinio kampų, dubens pasisukimo rezultatai pagal DIERS 3D instrukcijoje pateiktas rezultatų interpretacijas viršijo normas ir atitiko skoliozinès laikysenos rodiklius.

3. Remiantis W. W. Hoeger vizualiniu vertinimo metodu, tiriamųjų laikysenos įvertinimas atitinka geros laikysenos rodiklį. Berniukų laikysena kaklo ir viršutinejje stuburo dalyje buvo statistiškai reikšmingai prastesnè nei mergaičių. Nustatyta statistiškai reikšminga neigiama koreliacija tarp tiriamujų dubens pasisukimo laipsnio ir laikysenos vertinimo: kuo mažesnis paauglių dubens pasisukimo laipsnis, tuo geresnis laikysenos vertinimas pagal W. W. Hoeger skalę.

\section{Literatūra}

1. Obesity and Overweight. World Health Organization (Geneva).
2018. Prieiga per internetą: https://www.who.int/news-room/ fact-sheets/detail/obesity-and-overweight.

2. Vaikų sveikata 2017. Higienos instituto Sveikatos informacijos centras (Vilnius), 2018;97. Prieiga per internetą: http://hi.lt/lt/ vaiku-sveikata.html.

3. Katz LM, Guo Z, Cheema A, Laffel LM. Management of cardiovascular disease risk in teens with type 1 diabetes: perspectives of teens with and without dyslipidemia and parents. Pediatr Diabetes 2019;20(2):210-216.

https://doi.org/10.1111/pedi.12771

4. Raychaudhuri M, Sanyal D. Childhood obesity: determinants, evaluation, and prevention. Indian J Endocrinol Metab 2012;16(2):192-194.

5. Raza A, Jamshaid M, Riaz T, Bashir I, Majeed I, Akram W. Correlation of back pain with obesity and posture among teenagers. Anaesth Pain \& Intensive Care 2017;21(1):112-116.

6. Cruz-Gómez NS, Plascencia G, Villanueva-Padrón LA, JáureguiRenaud K. Influence of obesity and gender on the postural stability during upright stance. Obes Facts 2011;4(3):212-217. https://doi.org/10.1159/000329408

7. Bélanger M, Gray-Donald K, O'Loughlin J, Paradis G, Hanley J. When adolescents drop the ball: sustainability of physical activity in youth. Am J Prev Med 2009;37(1):41-49. https://doi.org/10.1016/j.amepre.2009.04.002

8. DIERS formetric 4D - Optical 4D spine and posture analysis. DIERS International GmbH 2009. Prieiga per internetą: http://osteopaatbrugge.be/wp-content/uploads/2018/06/ DIERS_3D-4D-spine-analysis.pdf. https://doi.org/10.1186/1748-7161-4-S2-O16

9. DIERS Biomedical Solutions. Information for the assessment 7122 AA 2009.

10. Krutulytė G., Valatkienė D., Samsonienė L., Dudonienė V., Švediené L. 11-12 metų moksleivių laikysenos vertinimas pagal W. W. K. Hoeger vizualinio laikysenos vertinimo metodiką. Visuomenès sveikata, 2007;1(36):16-20.

11. Mockutė I. Paauglių, turinčių antsvorị ir nutukimą, rizikos veiksnių ir laikysenos sąsajos. Magistratūros studijų programos baigiamasis darbas, LSMU (Kaunas), 2016.

12. Maciałczyk-Paprocka K, Stawińska-Witoszyńska B, Kotwicki T, Sowińska A, Krzyżaniak A, Walkowiak J, KrzywińskaWiewiorowska M. Prevalence of incorrect body posture in children and adolescents with overweight and obesity. Eur J Pediatr 2017;176(5):563-572.

https://doi.org/10.1007/s00431-017-2873-4

13. Brzęk A, Sołtys J, Gallert-Kopyto W, Gwizdek K, Plinta R. Body posture in children with obesity - the relationship to physical activity (PA). Pediatr Endocrinol Diabetes Metab 2016;22(4):148-155.

https://doi.org/10.18544/PEDM-22.04.0063

14. Wyszynska J, Podgórska-Bednarz J, Drzal-Grabiec J, Rachwal M, Baran J, Czenczek-Lewandowska E. et al. Analysis of relationship between the body mass composition and physi- 
cal activity with body posture in children. Biomed Res Int 2016;1-10.

https://doi.org/10.1155/2016/1851670

\section{POSTURE OF OVERWEIGHT AND OBESE CHILDREN IN EARLY ADOLESCENCE}

V.Strukčinskaitė, S.Trijonytė, B.Strukčinskienė, N.Strazdienè, A.Šidlauskienė, S.Griškonis

Key words: children, adolescents, overweight, obesity, posture. Summary

Nowadays one of the biggest public health problems is the rapidly increasing number of overweight and obese adolescents. During the early adolescence (10-14 years), adolescent population is facing with increasing health problems related to weight gain. Overweight and obesity are one of the main risk factors that can cause postural, orthopedic, and musculoskeletal problems for adolescents in the future.

The aim of the study is evaluation of posture parameters in overweight and obese adolescents.

Materials and Methodology. The study has been conducted in 2018-2019. In the research, 20 overweight and obese 10-14 years old adolescents participated. Such scientific tools as anthropometric measurement, Hoeger's visual posture scale, DIERS 3D diagnostic system, and statistical data analysis were used for the study.

Results and Conclusions. All individuals who participated in the study had a very high level of body fat percentage. Results indicate that the higher body mass index (BMI) of an adolescent is, the higher percentage of body fat is found in his/her body. Similarly, the higher percentage of body fat is, the lower percentage of skeletal muscles is indicated in adolescent's body $(p<0.05)$. In overweight and obese adolescents, the average rate of body posture was $40.10 \pm 2.93$ points which refers to a good body posture, according to the Hoeger's (1897) method. The neck and upper part of the spine, abdomen and lower part of the spine were evaluated as the weakest body parts. The neck and upper part of the spine got a statistically significantly worse result in boys than girls. In reference to DIERS 3D method, average results indicating the state of adolescent body posture were as follows: trunk imbalance $-4.40 \pm 2.64 \mathrm{~mm}$, pelvic tilt $-3.20 \pm 2.60 \mathrm{~mm}$, pelvic torsion $-3.10 \pm 1.80^{\circ}$, kyphotic angle $-54.75 \pm 11.36^{\circ}$, and lordotic angle $-49.60 \pm 9.32^{\circ}$. According to the DIERS 3D interpretation of the results, kyphotic and lordotic angles as well as pelvic torsion parameters exceed standards and indicate the scoliotic posture. The study results show a correlation between Hoeger's total points and pelvic torsion degree $\left(\mathrm{r}=-494^{*} ; \mathrm{p}=0.027\right)$.

Correspondence to: vaiva.struk@gmail.com

Gauta 2019-08-23 